\title{
STUDIES IN ANNONACEAE. XIII. THE ROLE OF MORPHOLOGICAL CHARACTERS IN SUBSEQUENT CLASSIFICATIONS OF ANNONACEAE: A COMPARATIVE SURVEY
}

\author{
J. Koek-Noorman, L. Y. Th. Westra and P. J. M. Maas ${ }^{1}$
}

\begin{abstract}
Summary
A comparative survey of several historical classifications of Annonaceae down to the subtribal level is given. The role of various key characters is briefly discussed. The present paper at the same time may be considered as an introductory paper to forthcoming publications of general studies on flower and fruit characters now being conducted at Utrecht.
\end{abstract}

\section{Introduction}

The history of systematic work on Annonaceae roughly covers the last one-and-a-half century. For a long time, the best-known authority on this family was, without any doubt, R. E. Fries, whose activities included the first six decades of this century. In recent years interest in Annonaceae has been renewed. At present a multidisciplinary project on the systematics of Annonaceae is in progress at Utrecht.

The Annonaceae form a large, generally easily recognizable and apparently natural family. Delimitation of tribes and genera, however, has been the subject of repeated discussion.

Since Dunal (1817) made a first subdivision of the family (including nine genera), many authors have turned their attention to the subject. Some of them confined themselves to certain geographical areas (Hooker and Thomson, 1855; Jovet-Ast, 1942; Sinclair, 1955). Others produced classifications based on a limited number of characters only (Le Thomas, 1983; Walker, 1971; Christmann, 1987). These fall outside the scope of the present paper and will not be treated here.

Three early classifications, i.e., pre-dating that of Bentham (1862) but following Dunal's work, should be mentioned briefly here. In Reichenbach's (1837) key, the family is divided into three tribes, one of these again into three subtribes. This, apparently, was the first time that a subdivision into tribes was made. Shortly thereafter, Endlicher (1839) published his classification with three tribes including 16 genera, to which are added five genera of uncertain status, and the genus Eupomatia which is placed under the heading "Anonaceis affines," bringing the total number of genera to 22. Agardh's (1858) treatment recognized four families: Hornschuchieae, Annonaceae, Monodoraceae, and Eupomatiaceae (although the endings vary, it is clear from the format of the work that all of the groups are of equivalent rank).

Bentham's (1862) classification, derived to some extent from that of Hooker and Thomson (1855), may be regarded as the first truly large-scale classification of the whole family. This was followed by the ones of Baillon (1868), Prantl (1891), Engler and Diels (1900), Engler (1897, 1908, 1915), Hutchinson (1923, 1964), and R. E. Fries (1959). Table 1 gives a comparison of subfamilies and tribes which are distinguished in these seven systems.

Diels (1932) expounds how, apart from a number of characters of lesser importance, one may recognize three characters of crucial importance for the taxonomy of Annonaceae, viz., apocarpy versus syncarpy, the shape of the petals, and the number of ovules per carpel. It seems, however, that there is little correlation between states of these three characters. The resulting reticulate pattern, as it were, seriously impedes classification of the family.

1 Institute of Systematic Botany, State University of Utrecht, Heidelberglaan 2, 3508 TC Utrecht, The Netherlands. 
The great difficulties encountered in attempts at classification that go further than merely producing a scheme for identification purposes are also aptly mentioned by Fries (1959): "Die Schwierigkeiten liegen in der richtigen Beurteilung des systematischen Wertes der einzelnen Merkmale wie auch in der oft noch unvollständigen Kenntnis der Blütenmorphologie vieler Gattungen."

All classifications down to the (sub)tribal level, so far, have relied to a greater or lesser extent upon the following characters:

1) carpels free or connate; 2) aestivation of petals; 3) number of petals; 4) relative length of petals; 5) differentiation in shape of petals; 6) petals free or connate; 7) shape of apex of stamen (apical prolongation of connective); 8) placentation and the number of ovules per carpel; 9) inflorescence position; 10) phyllotaxis; and 11) indument.

These characters will be discussed in the ensuing sections. Please note that the following text should be read in connection with Tables 1 and 2. The list of genera in Table 2 in the seventh column (under "Fries") is that as used by Fries in his 1959 survey. For the sake of clarity, the table follows the nomenclature as used by Fries. Any nomenclatural changes that were made by later authors may be found among the footnotes accompanying Table 2. Newer taxa, published in the post-Friesian era, are not included (the reader interested may want to consult in due time an enumeration of Annonaceous genera with bibliography and indication of current status, now being prepared in Utrecht and to be published shortly).

\section{Gynoecium Structure}

1. Placement of Monodora and Isolona.-Monodora Dunal has nearly always been placed in Annonaceae, though mostly in an isolated position. Both Dunal (1817) and de Candolle (1824) placed Monodora apart because of "one single carpel with numerous ovules" vs. "many carpels, free or connate." Only Agardh (1858) placed it in a separate family.

Although later authors consider the gynoecium of Monodora as a cyclic arrangement of connate carpels, they all agree that Monodora, together with the genus Isolona described later and regarded as closely related, has to be placed in a separate tribe or subfamily. The only exception is Bentham (1862) who includes Monodora in Mitrephoreae. (Delimitation of Mitrephoreae, in the course of time, has been the subject of much discussion; see Shape of Petals, part 1.)

2. Delineation of Annonineae/Annona-group.-Apart from the case of Monodora and Isolona, all Annonaceae carry carpels in spiral(s). These carpels are mostly free. In a number of genera they become fused. Fusion of carpels may be partial or complete. Syncarpy thus resulting is an important taxonomic character, though it not necessarily always indicates close relationship. The group where syncarpy dominates heavily is centered around the core of the large genera Annona and Rollinia, and the small genus Raimondia. These three genera are considered by nearly all authors to be very closely akin. Syncarpy here is complete in the bulk of species (only in Rollinia there are a few exceptions).

Rolliniopsis much resembles Rollinia, and is included in the Annona-group by Fries. It is distinct however by apocarpous fruits, for which reason it was placed in XylopineaeHexapetalae by Hutchinson.

Anonidium is also included in the Annona-group by Fries on the basis of carpels coalescing and immersed in the torus.

Ararocarpus, placed in Annonineae by Hutchinson, is referred to the Xylopia-group by Fries notwithstanding the fact that carpels, partly connate ("etwas vereinigt") at first, coalesce into a syncarpium. Sinclair (1958) came with a radically different approach to this genus in considering it as a freak of Nature: in fact it is a species of Meiogyne, distinct only in having an extremely high number of carpels. The resulting lack of space prevents a normal development of individual carpels; instead, a fusion occurs leading to the "abnormal" fruit. Anonidium, on the other hand, caused a problem here (see also Aestivation of Petals). Because of its imbricate inner petals, Anonidium is placed in Uvarieae by Engler 
and Diels and Hutchinson. Fries rather lays emphasis on the valvate outer petals and finds sufficient reason to put the genus in Unoneae (Annona-group).

3. The position of Fusaea. - The only genus with wholly syncardous fruits that has not been referred to the Annona-group at one time or another is Fusaea. It is in fact closely related to Duguetia, and it has even been treated as a section of that genus (e.g., Baillon, 1868: 336). Duguetia has always been classified in Uvarieae notably because of the imbricate petals. Fries distinguished a Duguetia-group, with Duguetia and Fusaea, and four more recently described genera, characterized by leaf-opposed flowers (inflorescences) with one basal ovule in each carpel. Carpels in the Duguetia-group are mostly sessile, and more or less connate at the base. The heterogeneous element here is Malmea with stipitate monocarps, which illustrates once more the relativity of syncarpy. It is worth mentioning that Sinclair (1955) regards Anonidium, Fusaea, and Pachypodanthium as a distinct, and the most advanced, group within Uvarieae.

\section{Aestivation of Petals}

Authors almost unanimously regard the difference between valvate and imbricate petals as one of the most important differentiating characters.

An exception are Engler and Diels, who do not recognize such an absolute difference between both aestivation types. Their first subdivision of Uvarioideae (Annonoideae of other authors) in four tribes (Table 1) is based rather on petal shape. This is further discussed in Shape of the Petals.

It may be useful to point out that the term "imbricate" has not always been used in exactly the same sense. As for Annonaceae, imbrication refers to overlapping of lateral margins in bud. Often, however, only the upper margins are seen to overlap. This can lead to problems of interpretation, which explains the case of, e.g., Sphaerothalamus, see hereafter.

1. Delimitation of Uvarieae. - Though not always on the same taxonomic rank, in all classifications there appears a group that is mainly characterized by imbricate petals (Uvarieae, Uvariinae). There is, however, no common opinion on the delimitation of this group.

When we look at the genera already known to Bentham (1862), we note that only two genera placed in Uvarieae by Bentham (and later authors) were removed by Fries: Sphaerothalamus and Porcelia.

Sphaerothalamus, according to older authors, has petals imbricate at the apex only, but it is included by Airy Shaw (1939: 279) and by Fries (1959) in Polyalthia, and thus it is classified in Unoneae by Fries.

Porcelia, in spite of imbricate petals, nevertheless is admitted by Fries as the only exception in Unoneae (Trigynaea-group) because of its obvious overall similarity with the other members of this group.

It is curious that Fries fails to mention Cardiopetalum and Froesiodendron, two other members of the Trigynaea-group, in this respect. These genera, with petals described as imbricate ("dachig"), mismatch in the same character as Porcelia. The genus Dasoclema is regarded by Fries as closely related to Monocarpia even to such an extent that both genera are placed in the Desmos-group of the Unoneae. However, petals in the former are described as "warscheinlich dachig," and in the latter as "klappig."

The genera Anonidium and Dendrokingstonia (Kingstonia) have created a problem for taxonomists due to a different aestivation of the two whorls of petals. Fries, for reason of valvate outer petals, removed the two genera from Uvarieae, where they had been placed because of imbricate inner petals. It may be noted that in Annona, as is also seen in Fries's key to the sections, species with imbricate inner petals occur as well. This is the case, among others, with the widely cultivated $A$. muricata.

Genera placed by later authors in Uvarieae, but not by Bentham, generally may be said to have had a troubled taxonomic history. The clearest example is Hexalobus: Bentham 
up to and including Hutchinson attribute a valvate aestivation to this genus. Engler and Diels create a separate group, Hexalobeae, based on plicate petals. Fries is the first to observe imbricate petals in Hexalobus and, accordingly, brings it in one group with Cleistochlamys, the other members being Asteranthe, Lettowianthus, and Ophrypetalum.

In a similar way Fries disagrees with earlier authors with regard to aestivation in Tridimeris and Anomianthus, and his taxonomy differs accordingly.

Heteropetalum, together with the genera Guatteriella and Guatteriopsis described later, is obviously so close to Guatteria that it naturally has to be placed together with it (Fries, 1942: 19), notwithstanding the valvate petals.

Finally, it may be worth noting that since the turn of the century the number of genera described has increased considerably. Uvarieae are subdivided by Fries in five groups, based on inflorescence position, aestivation of sepals, and placentation.

\section{Number of Petals}

The reader familiar with Annonaceae will know that the most common number of petals is six, in two whorls of three. Incidental occurrence of tetramerous flowers is regularly mentioned for species that normally have trimerous flowers. In Asimina tetramera Small the number of tetramerous flowers may even be roughly equal to the number of trimerous flowers in one population (Kral, 1960).

The aberrant genus Tetrameranthus, placed in a tribe of its own, among others, because of a phyllotaxis very different from that normally found in Annonaceae (see Phyllotaxis), has almost exclusively tetramerous flowers.

Hutchinson goes so far as to distinguish three subgroups within Xylopiineae solely based on the number of petals, viz., Hexapetalae, Tetrapetalae, and Tripetalae, later on (1964) referred to by him as Group A, Group B, and Group C, respectively. It should be added, though, that Engler and Diels had already recognized and keyed out Tetrapetalae earlier, also based on the number of petals. The purely artificial nature of this group involving the genera Disepalum, Tridimeris, and Uvariopsis is well demonstrated by Fries. Fries transfers Tridimeris to Uvarieae ("Pet. . . . zuerst warscheinlich dachig"). Uvariopsis (including Tetrastemma and the tripetalous (!) Thonnera), because of its single whorl of petals, is placed by Fries in the Monanthotaxis-group, and Disepalum is brought over to the Artabotrysgroup; both these groups fall within Unoneae.

Also the genera with a single whorl of three petals placed in Tripetalae by Hutchinson are classified by Fries in different groups of genera (see Table 1), though all within Unoneae.

Sinclair (1955) already points at intrageneric variation in number of petals, e.g., in Anaxagorea, Desmos, and Disepalum.

Fries, in his introduction (1959), sees a classification based on number of perianth parts as done by Hutchinson as good for practical identification purposes only, and sees hardly any connection to phylogenetic relationships. The number of petals may vary within some genera, e.g., Annona, Anaxagorea; in other cases three petals result from reduction of either the inner whorl (Dasymaschalon, Dennettia) or the outer whorl (Enantia). The trimerous genus Thonnera is considered so close to the tetramerous Uvariopsis that Fries unites the two. In this context it should be noted that Hutchinson's placing of Petalolophus in Tripetalae apparently is due to misinterpretation: the outer petals are present, though very small.

\section{Relative Size of Inner and Outer Petals}

In many genera inner and outer petals are comparable in size. It should be remarked that this is not necessarily always clear during (early) stages of development. Moreover, what is "equal" and what is "unequal" often is a matter of subjective choice. All this explains how investigators may have come to different interpretations. Notwithstanding this, authors in the past attributed great systematic value to relative length of petals. 


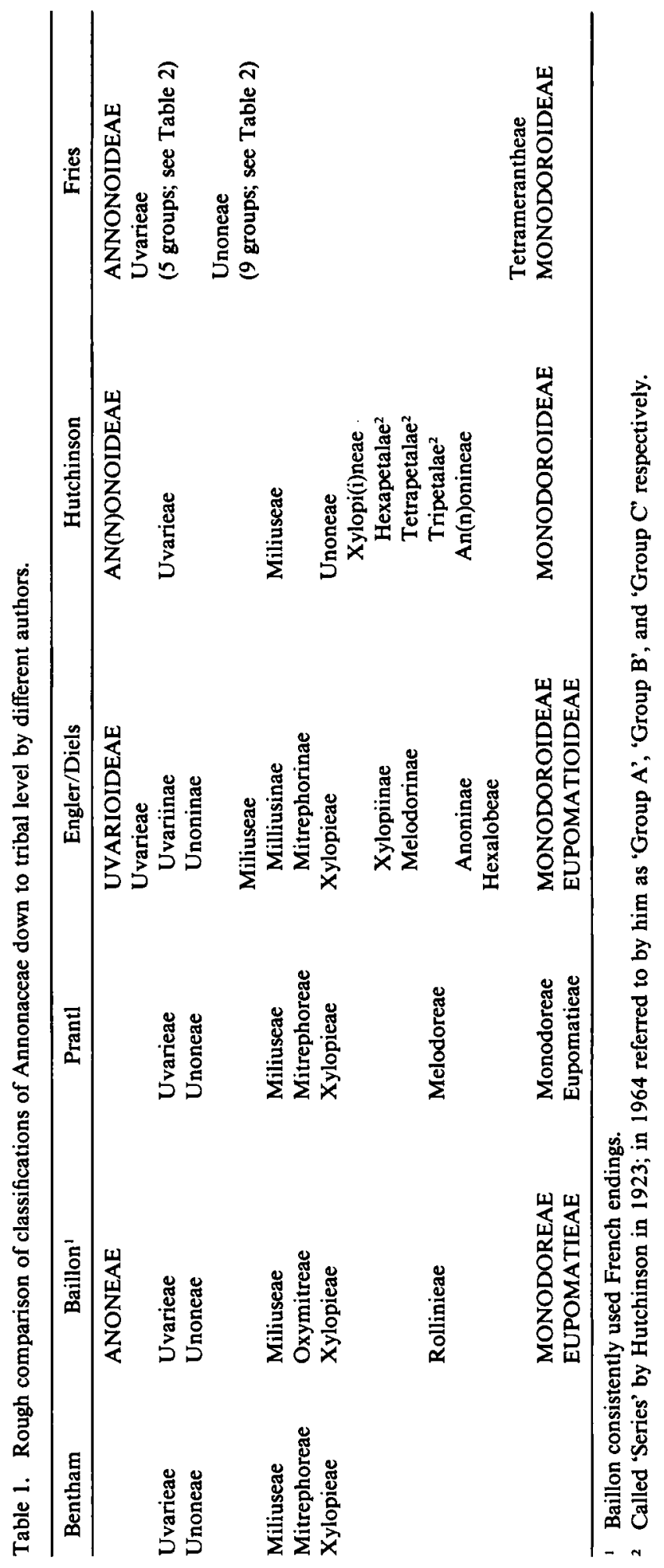


Baillon:

Miliuseae

\begin{tabular}{|l|}
\hline outer petals reduced \\
\hline
\end{tabular}
Prantl:

Melodoreae

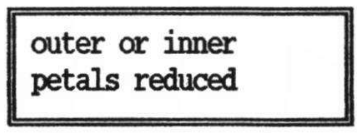

Miliuseae

stamens not dilatate above the anther
Engler/Diels:

Melodorinae

inner petals reduced
Miliusinae

outer petals reduced

Fig. 1. Definition of Miliuseae/Miliusinae on the one hand, and role of petal reduction on the other hand, in classifications of Annonaceae by Baillon, Prantl, and Engler and Diels, respectively.

Only Fries (1959: 41) pointed out that relative length of petals may vary greatly within some genera. Therefore, in his opinion, this character is only incidentally useful in delimitation of genera. Its main value lies on the specific level.

1. Delineation of Miliuseae or Miliusinae: Outer petals much shorter than inner petals, about equalling sepals. - Bentham was the first to distinguish Miliuseae, characterized by small sepals and outer petals, and large, valvate inner petals. In this group Bentham also included Eupomatia $\mathbf{R}$. Br. This genus was retained in Annonaceae by subsequent authors, though more and more in an isolated position, until Hutchinson restored it to the separate family of Eupomatiaceae still known today.

Circumscription of Miliuseae or Miliusinae, respectively, has not always been the same with various authors: this has been dependent upon priority of characters (see Fig. 1). Generally, the taxon included genera with reduced outer petals. Prantl, however, keyed out Miliuseae in the first place on stamens not dilatate above the anther (see also Apex of the Connective, part 1). Genera with either reduced inner or outer petals in Prantl's classification are grouped in Melodoreae. In the classification of Engler and Diels, however, Melodorinae stands for a group with lacking or reduced inner petals. Fries no longer recognized Miliuseae, which is the logical consequence of the low weight that he assigns to reduction of organs, as has been discussed before.

Orophea presents a problem in itself as it is distinguished by both unguiculate, mitriform inner petals and reduced outer petals. Baillon's transfer of Orophea from Miliuseae to Oxymitreae ( $=$ Mitrephoreae), and the reverse action by Hutchinson, are therefore easy to understand. Baillon at the same time brought Phaeanthus (including Heteropetalum and Piptostigma) from Mitrephoreae sensu Bentham to Miliuseae. This remained there up to and including Hutchinson's classification.

Engler and Diels, and Hutchinson, also added genera to Miliuseae: Anomianthus and Cymbopetalum, as well as Fenerivia and Marsypopetalum that had been described in the meantime.

The genus Bocagea (with six equal, thin, petals) has been placed now in Miliuseae and at other times in Unoneae.

2. Melodorinae sensu Engler and Diels: Reduced inner petals. -As has already been mentioned in the preceding section, Engler and Diels alone recognized the Melodorinae as characterized by the lack or strong reduction of inner petals. This figures as a subgroup of Xylopieae which are characterized by thick petals. Melodorinae includes the genera $E b u-$ 


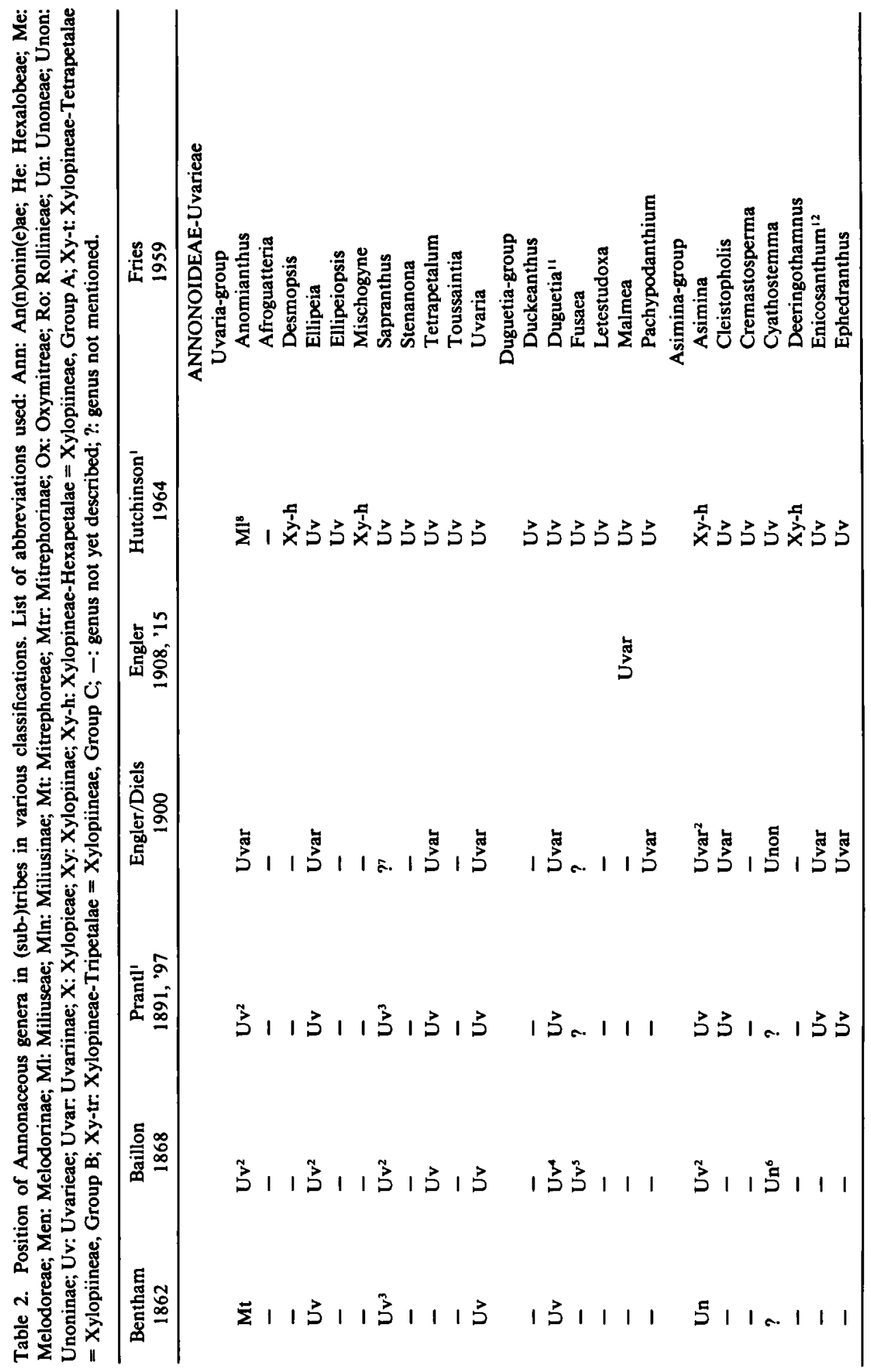




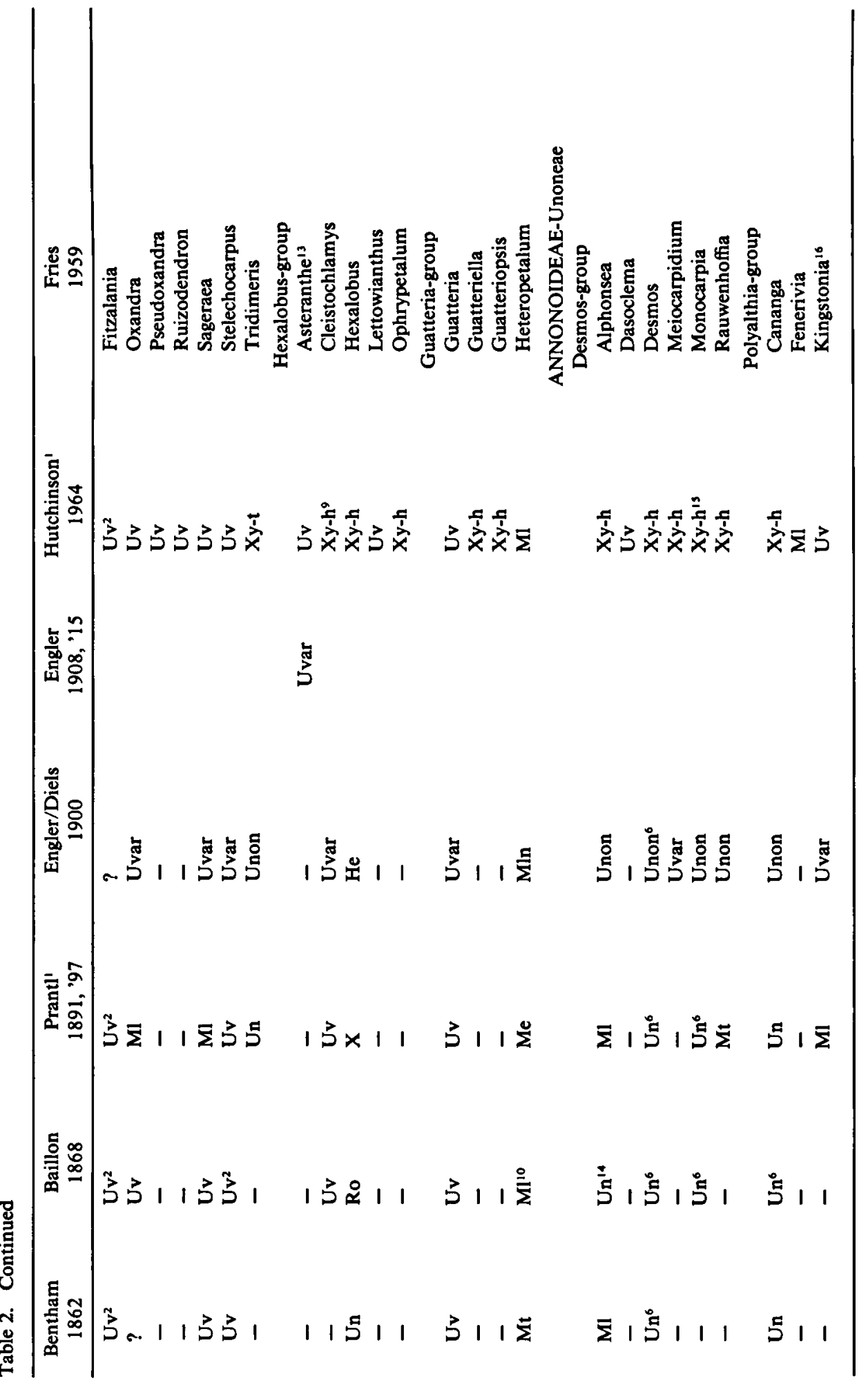




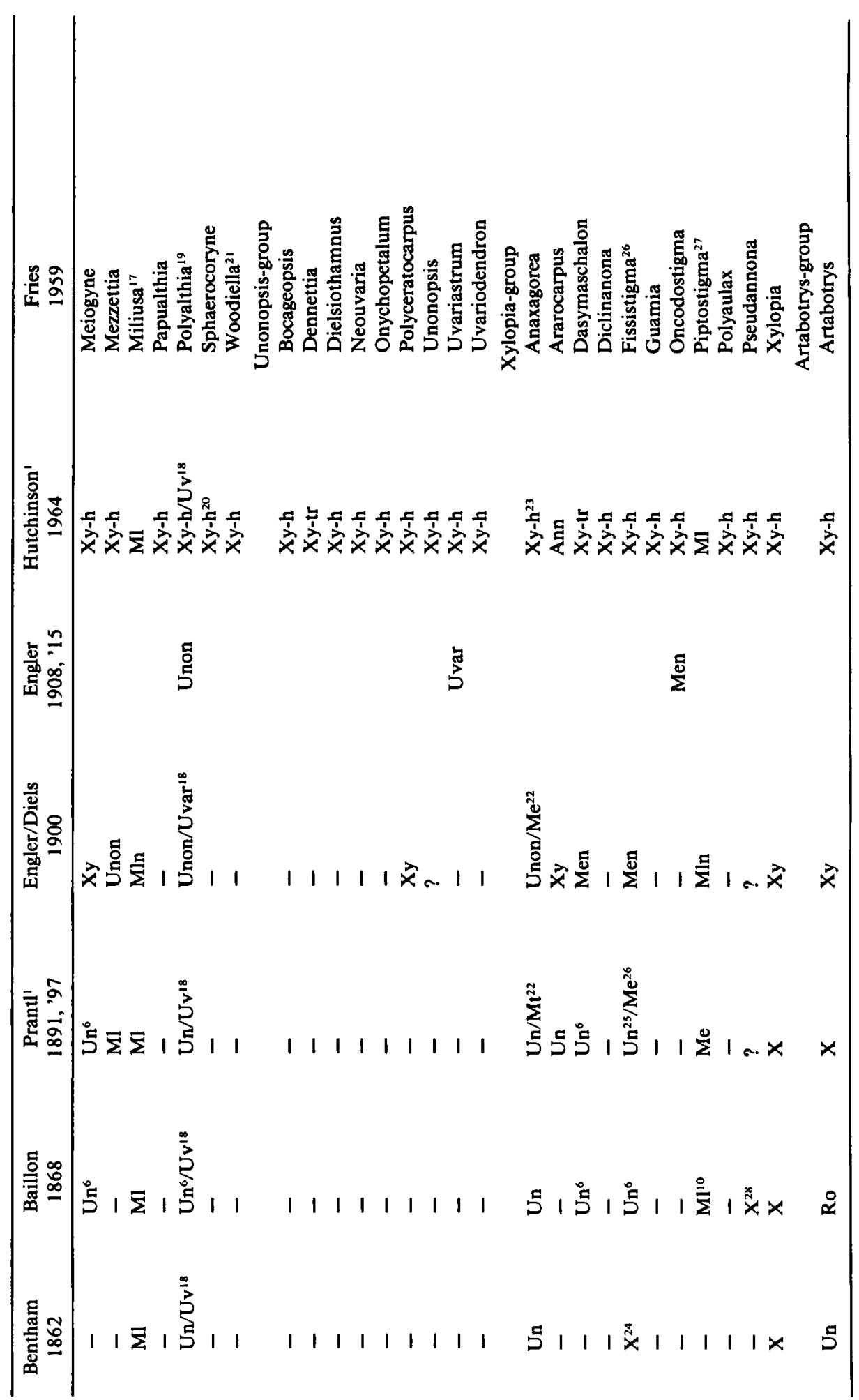




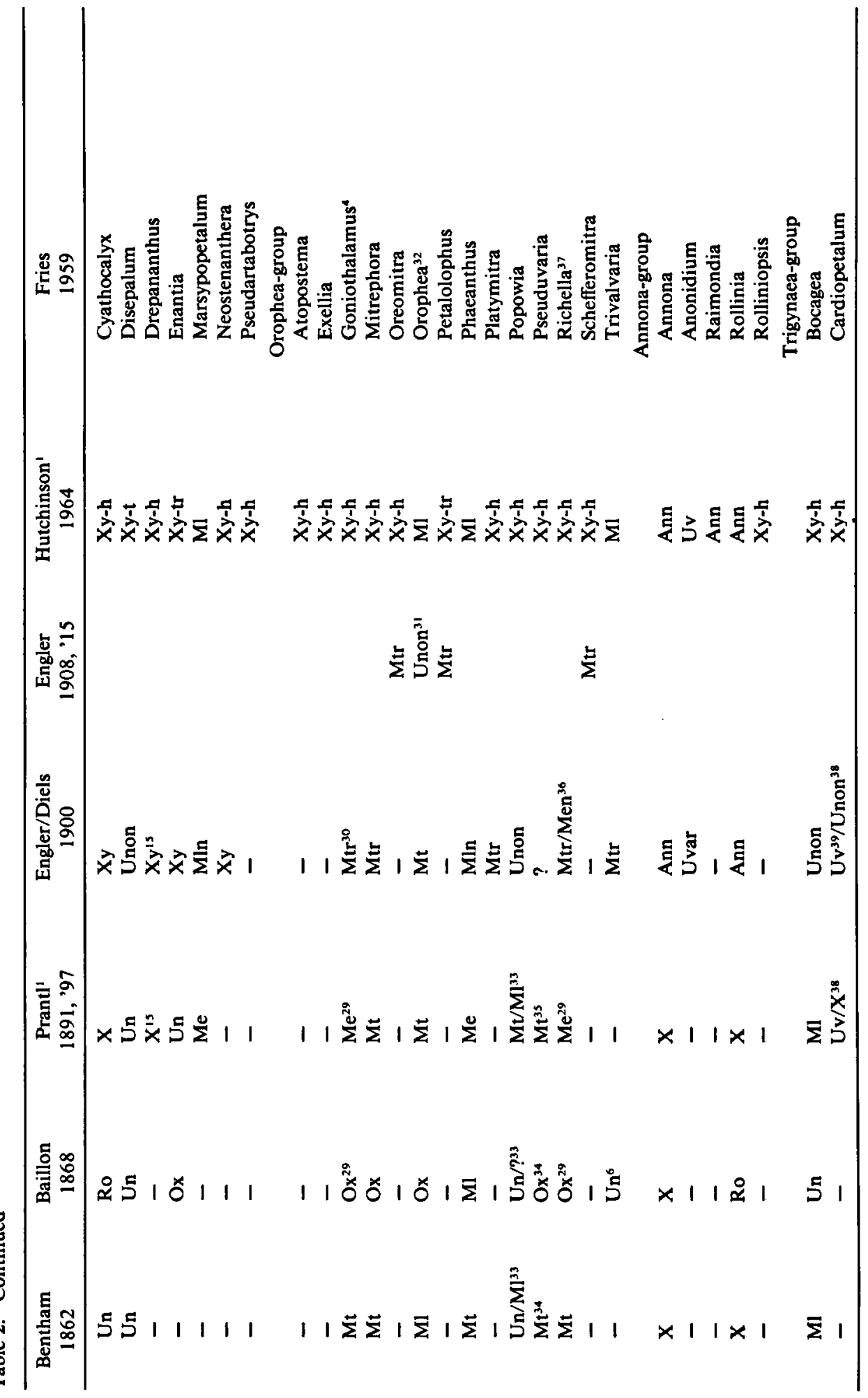




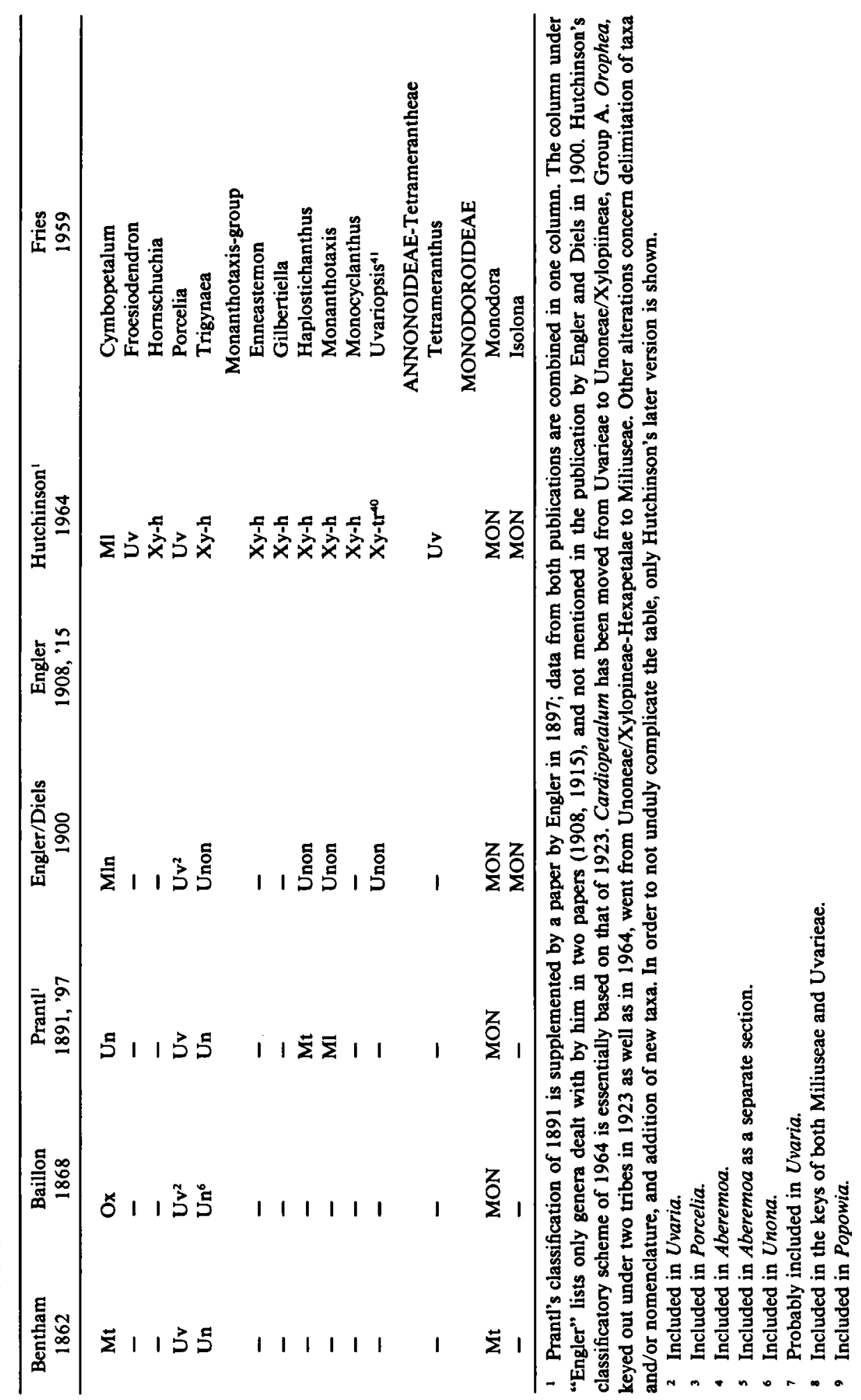




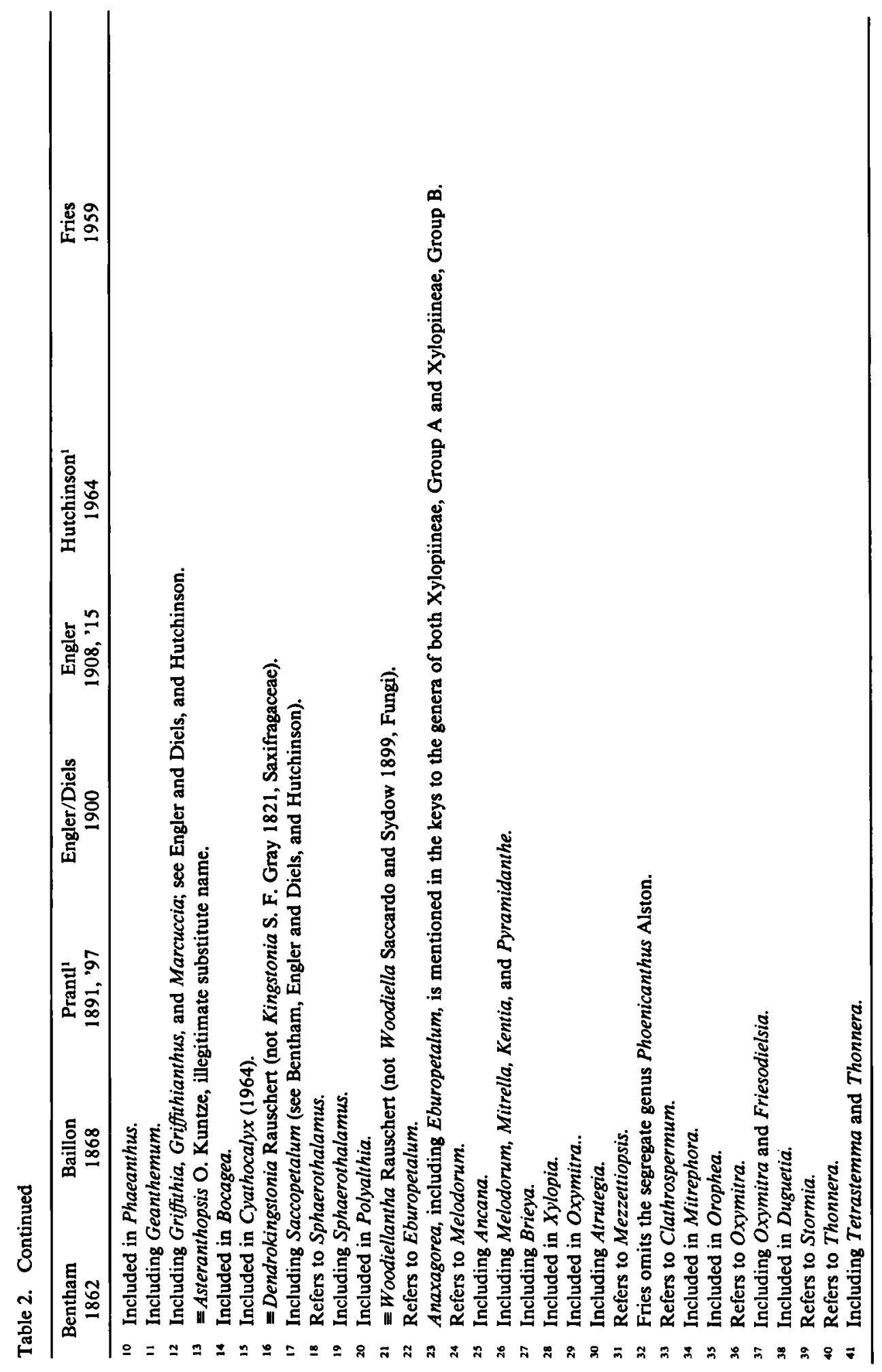


ropetalum (=Anaxagorea), Dasymaschalon, and Fissistigma. It is noteworthy that, in a sense, this idea is also adopted by Fries: Xylopia and the three genera just mentioned form part of the Xylopia-group is his classification, characterized by thick, \pm wholly contiguous inner petals with concave bases.

3. Melodoreae sensu Prantl: Either reduced inner or outer petals. - This group, already mentioned above, cannot be but a highly artificial group. It is not surprising, therefore, that no other authors adopted it. Engler and Diels, in fact, rejected it and transferred the genera to Miliusinae, Mitrephorinae, and Melodorinae.

\section{Shape of the Petals}

Engler and Diels were the first authors to use this character on the tribal level. Their subdivision of Uvarioideae (Annonoideae of other authors) is given here:

-petals about equal, flat, rarely appendaged: Uvarieae;

-petals valvate, mostly unequal, inner petals often appendaged: Miliuseae (subdivided in Miliusinae and Mitrephorinae based on absence or presence of connivent inner petals);

-petals plicate: Hexalobeae;

-petals thick, valvate, inner petals smaller than outer petals, or lacking: Xylopieae.

The shape of the petals, however, is difficult to describe in terms useful for systematic purposes. There is only one group out of those just mentioned that, at first sight, seems quite natural (Mitrephorinae). The other three groups could hardly claim to be that.

1. Delineation of Mitrephoreae/Mitrephorinae: Inner petals hood-like. - In certain members of the Annonaceae, all with valvate petals, the distinctly smaller inner petals are contiguous apically, thereby forming a cap or mitre over the stamens and carpels. In all classification systems, except Hutchinson's, there is included a tribe or subtribe thus defined (Mitrephoreae, Mitrephorinae, Oxymitreae, Orophea-group).

Nevertheless, this character, too, appears open to various interpretations: what one person would call a "hood" will not necessarily be recognized as such by another! Table 2 shows that there is unanimity only in the case of comparatively few genera: Goniothalamus, Mitrephora, and Richella (Oxymitra). Platymitra, published somewhat later, can also be mentioned here.

Monodora was placed already by Baillon in a separate tribe, in which it has remained since. Other genera have been tossed to and fro between Mitrephoreae and other groups, such as Miliuseae (Orophea, Phaeanthus, and Cymbopetalum). Popowia and Rauwenhoffia are placed in Unoneae by, among others, Engler and Diels. Anomianthus, Heteropetalum, and Enantia fare even more oddly. Fries expands the Orophea-group with nine more genera, although with some doubts as regards two of these, viz., Trivalvaria and Atopostema.

2. Xylopia and its allies: Inner petals thick, valvate, more or less hollow at the base.$X y l o p i e a e$ were defined by Bentham based on, among others, thick, valvate petals. Genera frequently mentioned in this context, beside Xylopia, are Annona, Artabotrys, Cyathocalyx, and Rollinia (Rollinieae sensu Baillon).

Other genera are placed incidentally in Xylopieae. Although with some generalization, one might say that the three subtribes of Xylopieae, viz., Unoninae, Xylopiinae, and Mitrephorinae sensu Engler and Diels agree with the Xylopia-, Artabotrys-, and Annonagroups sensu Fries.

Hutchinson has a different approach: the three subtribes by Engler and Diels just mentioned are united in Xylopi(i)neae, which is subdivided in three groups based on number of petals (already mentioned under the section Number of Petals), albeit with easy identification as the main goal.

\section{Sympetalous Flowers}

In most genera petals are free. Although sympetaly occurs in Annonaceae, there is no author, with the exception of Fries (see below), who distinguishes major groups based on 
this character state. Occurrence of both choripetalous and sympetalous flowers is found in Annona. The same holds for the small genus Fusaea. The fully sympetalous state may be seen in such widely divergent genera as Rollinia and Isolona.

1. The Monanthotaxis-group sensu Fries. - The group with the largest concentration of genera with sympetaly (though in various degree) is the Monanthotaxis-group of Fries. This group also includes genera with free petals, however. On the other hand Fries moves the manifestly sympetalous Disepalum to the Artabotrys-group, where it admittedly remains a heterogeneous element.

\section{Apex of the Connective}

In most Annonaceae the apex of the connective characteristically is prolonged into a dilatation that is usually shield-like. This connective shield has a protective function: it keeps the developing fertile parts of the flower away from voracious insects (Gottsberger, 1970).

1. Miliuseae sensu Prantl. - In Prantl's (1891) concept Miliuseae are keyed out in the first place on stamens not dilatate above the anther (though the connective may still be prolonged into an appendage of very distinct shape). This group includes seven genera, among them Oxandra and Sageraea, genera placed in the Uvarieae in all other classifications.

No other authors, however, assign such importance to the apex of the connective as did Prantl. Sinclair perhaps comes closest to Prantl's concept in defining Miliuseae (six genera) as having, among other things, "stamens few, loosely imbricate, anther cells not covered by the flat-topped, rounded or pointed connectives" (Sinclair, 1955: 178). Engler and Diels use this character well below tribal level, to key out genera. Hutchinson characterizes the connective in Uvarieae as "almost invariably truncate and hiding the loculi"; in both the other tribes, viz., Miliuseae and Unoneae, he considers this character as inconstant.

Fries points out that stamen shape may vary even within a genus, for instance in Annona where the connective shield varies from large to strongly reduced, and Duguetia where some species lack the connective shield typical for the genus.

\section{Placentation and the Number of Ovules}

In Annonaceae, both lateral (marginal) and basal placentation are found. Monodoroideae, with numerous parietal ovules, are aberrant in this regard. Contradictory views as to the morphological nature of the fruit of Monodoroideae have already been mentioned in the first section. At present, the increasingly popular opinion seems to be that this fruit consists of a single carpel with laminally attached ovules (van Setten, pers. comm.).

Most authors use the number of ovules per carpel as a differentiating character at the genus level or below. All authors seem to admit that lateral and basal placentation may occur together in the same taxon and, thus are of little general taxonomic value. In this context it should be remarked that in actual practice it is often hard to determine whether a single ovule that one observes at the bottom of the ovary is basal or lateral! Uvarieae and Unoneae in the sense of Fries are also heterogeneous in this respect. Fries (1959), however, uses placentation to define generic groups, with the exception of the Artabotrys and Asimina groups. Yet Fries admits, giving Ephedranthus and Unonopsis, among others, as examples, that it is often difficult to determine if a basal ovule should not rather be taken as a derived condition from an ancestral form with lateral ovule(s), and that "... Gattungen mit basalen oder parietalen Samen vom phylogenetischen Gesichtspunkt oft in eine und dieselbe Gattungsgruppe aufgenommen werden können" (Fries, 1959: 42).

\section{Inflorescence Position}

This character, curiously enough, drew little attention from authors prior to Fries. Inflorescence position and structure is discussed at some length in two papers by Fries (1919, 
1959), to which the reader is referred. Flowers in Annonaceae appear singly or in monochasial structures. These originate from leaf axils or from the internode (leaf-opposed, supra-axillary, infra-axillary). Both conditions may be explained as derivations from a terminal anthotaxis.

The character, though variable at tribal level, is usually very constant at the level of Fries's groups, and plays an important role in keying out groups, particularly in Uvarieae. Only in a few genera are both character states found, such as in Anaxagorea (Maas and Westra, 1984, 1985).

\section{Phyllotaxis}

One of the distinct features of Annonaceae is the phyllotaxis: all genera (except for Tetrameranthus) are characterized by leaves in two rows (1/2). As already mentioned in the section Number of Petals, this genus is also exceptional in having 4-merous perianth whorls. There are additional characters which place that genus in an isolated position within the family and which need not be mentioned in detail here. The reader is referred to Fries $(1939,1959)$, Westra (1985), and Koek-Noorman et al. (1988).

Apart from Tetrameranthus, there are few reported cases of a phyllotaxis other than 1/2. Treub (1883) described leaves in three rows on branches in certain species of Artabotrys. The same occurs possibly in Annona crotonifolia (Fries, 1959: 8). The latter two genera are unrelated; moreover, both normally have leaves in two rows. Wagner's (1906) report of a $2 / 5$ phyllotaxis in Disepalum anomalum is based on a wrong assumption from herbarium study of flowering shoots, as is discussed by Johnson (in press).

\section{Indument}

Most genera in Annonaceae, if not glabrous, possess simple trichomes. Stellate trichomes have been reported in several genera by now. A few genera have a very distinctive indument of scales.

Hutchinson $(1964: 73,76)$ suggests that the majority of genera (seven) with stellate or lepidote indument is found in Uvarieae. Only four genera remain in other tribes. This is definitely not true. Generic descriptions by Fries (1959) show that stellate hairs occur in at least four more genera beside those mentioned by Hutchinson. These genera are all classified by Hutchinson in tribes other than Uvarieae.

In Fries's classification, genera with stellate and/or lepidote indument are found in six groups. Four genera out of these are mentioned as heterogeneous in the sense that they contain both species with simple and with stellate hairs.

Although it is possible that stellate trichomes may emerge in more genera than are now known to possess them, it seems unlikely that this feature is ever going to play an important role on the tribal level.

\section{Conclusion}

The foregoing has illustrated clearly that there is no consensus among previous authors on classification of the Annonaceae. It hardly seems possible to indicate which one of the classifications is the best. Altogether there seems to be agreement most on Uvarieae, although size and contents of this tribe vary somewhat.

There is much confusion about relationships among genera that are grouped under Unoneae by Fries, as a result of apparent lack of correlation of characters. Whether focus is on reduction (suppression) of one whorl of petals, or variation in shapes of petals, or variation in shapes of stamens, etc., in each case the resulting classification is a different one. It then largely becomes a matter of taste which character one wants to assign the most value, and, consequently, what classification one will prefer. All authors have had to admit, in one way or another, that their classificatory schemes were unsatisfactory.

The seven classifications mentioned in the introduction are all based, for the most part, 
on floral characters listed there (nos. 1-8). Much less attention was paid to inflorescence structure and vegetative characters (nos. 9-11). Fruits and seeds also have been much neglected. The seeming uniformity of fruits and seeds as well as their paucity in older collections may account for this.

Since Fries and Hutchinson published their last classifications in the late 1950's and early 1960's, respectively, much new material has been brought in. More complete datasets may now be available for taxa still very incompletely known 25 years ago. This applies to fruits not in the least. Furthermore, after Fries's integral treatment, nine new genera were described. One of the urgent studies needed now is a worldwide survey of fruit and seed characters. The greatly increased number of collections, however, has also brought much new data on flowers and, or course, the other structures mentioned in the foregoing sections as well. This makes the need for a modern worldwide survey of floral characters equally important.

As part of the recent research activities by the Annonaceae Project group in Utrecht (Maas, 1983, 1984), two publications will appear in this context. One will feature a descriptive study of flowers of Annonaceous genera from the whole world (van Heusden, in prep.). The second one will provide descriptions and character analyses of fruits and seeds of Annonaceae on the generic level also worldwide (van Setten, in prep.).

\section{Literature Cited}

Agardh, J. G. 1858. Pp. 65-66, 126-127. In: Theoria systematis plantarum. C. W. K. Gleerup, Lund.

Airy Shaw, H. K. 1939. Additions to the flora of Borneo and other Malay Islands: XII. The Annonaceae of the Oxford University Expedition to Sarawak, 1932. Bull. Misc. Inform. 1939: 275-290.

Baillon, H. 1868. Histoire des plantes, 1: 193-288. L. Hachette et Cie, Paris, London, Leipzig.

Bentham, G. 1862. In: G. Bentham and J. D. Hooker (eds.), Genera plantarum, 1(1): 20-29. A. Black, London.

Candolle, A. P. de. 1824. Prodromus systematis naturalis regni vegetabilis, 1: 83-94. Treuttel et Würtz, Paris.

Christmann, M. 1987. Systematische Anatomie der Annonaceen-Samen. Thesis, Kaiserslautern.

Diels, L. 1932. Die Gliederung der Anonaceae und ihre Phylogenie. Sitzungsber. Preuss. Akad. Wiss., Phys.-Math. Kl. 1932: 77-85.

Dunal, M. F. 1817. Monographie de la famille des Anonacées. Treuttel et Würtz, Paris.

Endlicher, S. 1839. P. 830-835. In: Genera plantarum secundum ordines naturales disposita. Fr. Beck, Wien.

Engler, A. 1897. In: A. Engler and K. Prantl (eds.), Die natürlichen Pflanzenfamilien, Nachtr. I: 159161. Wilhelm Engelmann, Leipzig.

1908. In: A. Engler and K. Prantl (eds.), Die natürlichen Pflanzenfamilien, Nachtr. III: 112120. Wilhelm Engelmann, Leipzig.

. 1915. In: A. Engler and K. Prantl (eds.), Die natürlichen Pflanzenfamilien, Nachtr. IV: 8991. Wilhelm Engelmann, Leipzig.

and L. Diels. 1900. I. Übersicht über die bekannten Gattungen der Anonaceen und Beschreibung einiger neuen Gattungen dieser Familie aus dem tropischen Afrika. Notizbl. Bot. Gart. Berlin-Dahlem 3(23): 45-59.

Fries, R. E. 1919. Studien über die Blütenverhältnisse bei der Familie Anonaceae. Acta Horti Berg. 6(6): 3-48.

1939. In: A. C. Smith (ed.), Notes on a collection of plants from British Guyana. Lloydia 2: $179-180$.

1942. In: K. Suessenguth (eds.), Neue Pflanzen aus Costa Rica, insbesondere vom Chirripó grande 3837 m. Bot. Jahrb. Syst. 72: 273-274.

1959. In: A. Engler and K. Prantl (eds.), Die natürlichen Pflanzenfamilien Ed. 2, Band 17a, II: 1-171. Duncker und Humblot, Berlin.

Gottsberger, G. 1970. Beiträge zur Biologie von Annonaceen-Blüten. Oesterr. Bot. Z. 118: 237-279.

Hooker, J. D. and T. Thomson. 1855. Flora indica, 1: 86-153. W. Pamplin, London. 
Hutchinson, J. 1923. A contribution towards a phylogenic classification of flowering plants. II. The genera of Annonaceae. Bull. Misc. Inform. 1923: 241-261.

- 1964. The genera of flowering plants. Dicotyledones, 1: 71-108. Clarendon Press, Oxford.

Johnson, D. M. Submitted. Revision of Disepalum (Annonaceae). Brittonia.

Jovet-Ast, S. 1942. Recherches sur les Anonacées d'Indochine-Anatomie foliaire-Répartition géographique. Mém. Mus. Natl. Hist. Nat., n.s., 16: 125-308.

Koek-Noorman, J., M. Zandee and L. Y. Th. Westra. 1988. Studies in Annonaceae. VIII. A. cladistic analysis of Tetrameranthus. Taxon 37(2): 346-353.

Kral, R. 1960. A revision of Asimina and Deeringothamnus. Brittonia 12: 233-278.

Le Thomas, A. 1983. Morphologie et palynologie des Annonacées africains: Interrelations phylogéniques. Bothalia 14: 825-831.

Maas, P. J. M. 1983. Project Systematics of Annonaceae. Taxon 32(3): 528-529.

- 1984. The Annonaceae Project. Taxon 33(4): 800-801.

and L. Y. Th. Westra. 1984. Studies in Annonaceae. II. A monograph of the genus Anaxagorea A. St.Hil. Part I. Bot. Jahrb. Syst. 105(1): 73-134.

and - 1985. Studies in Annonaceae. II. A monograph of the genus Anaxagorea A. St.Hil. Part II. Bot. Jahrb. Syst. 105(2): 145-204.

Prantl, K. 1891. Anonaceae. In: A. Engler and K. Prantl, Die natürlichen Pflanzenfamilien, III. Teil, 2. Abteilung: 23-39. Wilhelm Engelmann, Leipzig.

Reichenbach, H. G. L. 1837. Handbuch des natürlichen Pflanzensystems, 278. In der Arnoldischen Buchhandlung, Dresden und Leipzig.

Sinclair, J. 1955. A revision of the Malayan Annonaceae. Gard. Bull. Straits Settlem., ser. 3, 14: $149-516$.

-. 1958. Ararocarpus- A monstrosity. Gard. Bull. Straits Settlem., ser. 3, 17: 93-95.

Treub, M. 1883. Sur une nouvelle catégorie de plantes grimpantes. Ann. Jard. Bot. Buitenzorg 3: $44-66$.

Wagner, R. 1906. Ueber den Aufbau des Disepalum anomalum Hook. fil. Sitzungsber. Kaiserl. Akad. Wiss., Math.-Naturwiss. Cl., Abt. 1 105: 881-894.

Walker, J. W. 1971. Pollen morphology, phytogeography, and phylogeny of the Annonaceae. Contr. Gray Herb. 202: 1-132.

Westra, L. Y. Th. 1985. Studies in Annonaceae. IV. A taxonomic revision of Tetrameranthus R. E. Fries. Proc. Kon. Ned. Akad. Wetensch. Ser. C. 88(4): 449-482. 